\title{
Genetic Diversity and Population Structure of Cucurbit Gummy Stem Blight Fungi Based on Microsatellite Markers
}

\author{
Marin Talbot Brewer, Manisha Rath, and Hao-Xi Li
}

Department of Plant Pathology, University of Georgia, Athens.

Accepted for publication 19 January 2015.

\begin{abstract}
Brewer, M. T., Rath, M., and Li, H.-X. 2015. Genetic diversity and population structure of cucurbit gummy stem blight fungi based on microsatellite markers. Phytopathology 105:815-824.

Combining population genetics with epidemiology provides insight into the population biology of pathogens, which could lead to improved management of plant diseases. Gummy stem blight, caused by three closely related species of Stagonosporopsis-Stagonosporopsis cucurbitacearum (syn. Didymella bryoniae), S. citrulli, and S. caricae-is a devastating disease of cucurbits worldwide. Sources of inoculum for epidemics, mechanisms of dispersal, and the mating system of these species are not well understood. To improve our knowledge of gummy stem blight epidemiology, we developed 18 polymorphic microsatellite markers by combining microsatellite motif enrichment with next-generation sequencing. When tested on 46 isolates from diverse cucurbit hosts and regions, the markers were robust for the

dominant and widely distributed S. citrulli. Within this species, we found no population structure based on broad-scale geographic region or host of origin. Using the microsatellites, a rapid polymerase chain reaction-based method was developed to distinguish the three morphologically similar species causing gummy stem blight. To better understand dispersal, reproduction, and fine-scale genetic diversity of $S$. citrulli within and among watermelon fields, 155 isolates from two field populations in Georgia, United States were genotyped with the 18 microsatellite loci. Although dominant and widespread clones were detected, we found relatively high genotypic diversity and recombinant genotypes consistent with outcrossing. Significant population genetic structure between the two field populations demonstrated that there is regional geographic structure and limited dispersal among fields. This study provides insight into the fine-scale genetic diversity and reproductive biology of the gummy stem blight pathogen $S$. citrulli in the field.
\end{abstract}

A thorough understanding of plant disease epidemics includes identifying sources of inoculum (Archie et al. 2009; Xhaard et al. 2012), knowledge of the pathogen's reproductive biology (Maciel et al. 2014; Yuen and Andersson 2013), and uncovering genetic structure of the pathogen populations (Rieux et al. 2011). Population genetic analyses can be used to track the dispersal and spatial distribution of genotypes in order to reveal inoculum sources (Prussin et al. 2014; Zwankhuizen et al. 2000) and to identify population subdivision resulting from restricted gene flow due to geographic structure (Brewer et al. 2012; Brewer and Milgroom 2010), host specialization (Fournier and Giraud 2008; Frenkel et al. 2012), and ecological adaptation among populations (Capelle and Neema 2005). Additionally, measures of genotypic diversity and recombination can be used to infer whether pathogen populations are clonal, sexual, or have mixed modes of reproduction (Maciel et al. 2014; Rieux et al. 2011). Combining population genetics with epidemiology provides insight into the population biology of pathogens (Milgroom and Peever 2003; Xhaard et al. 2012), which may lead to improved management of plant diseases, particularly if we can target inoculum sources, limit pathogen reproduction, or uncover distinct populations that may require unique management strategies.

We are interested in uncovering the population structure and both the broad- and fine-scale genetic diversity of the cucurbit gummy stem blight pathogen to better understand the epidemiology of this disease. The pathogen can overwinter in plant debris (Keinath 2002), be detected at very low incidence in seed, and infect transplant seedlings in the greenhouse (Keinath 2011); however, the major source of inoculum that initiates epidemics in the field is unclear.

Corresponding author: M. T. Brewer; E-mail address: mtbrewer@uga.edu

http://dx.doi.org/10.1094/PHYTO-10-14-0282-R

(C) 2015 The American Phytopathological Society
It has recently been determined that gummy stem blight is caused by three closely related fungal species: Stagonosporopsis cucurbitacearum (syn. Didymella bryoniae and Phoma cucurbitacearum), S. caricae (syn. P. caricae-papayae), and S. citrulli (Stewart et al. 2015). Gummy stem blight is a devastating and worldwide disease of the Cucurbitaceae family, including watermelon, cucumber, cantaloupe, muskmelon, squash, pumpkin, and gourds (Chiu and Walker 1949; Keinath 2011), especially in humid environments. However, no specialization to cucurbit host species has been detected, regardless of the host of origin (Chiu and Walker 1949; Keinath et al. 1995; Kothera et el. 2003; Lee et al. 1984) (Stewart et al. 2015). Symptoms of gummy stem blight include leaf spots and necrotic, water-soaked lesions on stems and fruit. The fungus can cause symptoms on all aboveground plant parts and is referred to as black rot when it affects the fruit. Pumpkin and winter squash are particularly susceptible to black rot. After primary infection, abundant conidia are produced within pycnidia produced on vines, leaves, and other aboveground plant parts. The conidia are splash dispersed short distances to nearby plants, which can lead to rapid epidemics under wet conditions (CaféFilho et al. 2010; Wiant 1945). Pseudothecia containing ascospores are produced simultaneously (Café-Filho et al. 2010) or later in the growing season, usually on vines (Schenck 1968). Dispersal distance by ascospores has not been studied (Keinath 2011). Seed may become infested or infected by way of flower and fruit infection (de Neergard 1989).

Previous studies on the population biology of the causal pathogens have been conducted on a broad geographic scale. Genetic diversity was examined by using a single nuclear gene sequence, random amplified polymorphic DNA (RAPD) (Somai et al. 2002), and amplified fragment length polymorphism (AFLP) (Kothera et al. 2003). These studies showed that gummy stem blight is caused by at least two genetically distinct groups that are morphologically indistinguishable, with overlapping geographic and host ranges (dos Santos et al. 2009; 
Keinath et al. 1995; Kothera et al. 2003; Somai et al. 2002;). Recently, a multilocus sequencing study of diverse isolates from different cucurbit hosts around the world showed that gummy stem blight is caused by three distinct but closely related and morphologically similar species of Stagonosporopsis (Stewart et al. 2015), one of which is the papaya pathogen $S$. caricae. This pathogen was previously described as affecting only papaya (Boerema et al. 2004); therefore, some isolates of $S$. caricae from cucurbits had been previously misidentified as $S$. cucurbitacearum (D. bryoniae) due to the host species of origin and similar morphology. The two genetic groups were determined to be two phylogenetically distinct species; therefore, the name $S$. citrulli was assigned to the new species (Stewart et al. 2015) while the other species retained the name $S$. cucurbitacearum. The three species affect cucurbits similarly but only $S$. caricae is pathogenic to papaya (Stewart et al. 2015). S. citrulli is the most abundant, genetically diverse, and geographically widespread of the three species (Stewart et al. 2015). Although previous studies have demonstrated that there is genetic diversity among gummy stem blight isolates, diversity within and among populations at the field level needs to be addressed to uncover sources of inoculum, track pathogen dispersal, and better understand the reproductive biology of these fungi, especially the dominant species S. citrulli, in the field.

Previous studies on gummy stem blight isolates indicate that the fungus is self compatible, or homothallic (Chiu and Walker 1949), but some level of outcrossing, which would result in recombinant genotypes and contribute to increased diversity, may be possible because many self-compatible fungi are capable of outcrossing (Atallah et al. 2004; Debuchy and Turgeon 2006). The fungus reproduces asexually and sexually by the production of conidia and ascospores, respectively. The asexual and sexual reproductive states form in culture (Corlett 1981; Wiant 1945) and are observed on a variety of cucurbit hosts (Keinath 2014; Wiant 1945). However, it is not possible to determine which of the three Stagonosporopsis spp.--all of which could have possibly been identified as D. bryoniae-was observed in previous studies. Fine-scale studies on the diversity and population structure of the gummy stem blight pathogens will improve our understanding of the reproductive mode and mating system of this fungus and the capacity of populations to evolve resistance to multiple fungicides or overcome resistance to different host genotypes, knowledge that is critical for effective disease management (McDonald and Linde 2002; Milgroom 1996).

In order to answer these questions about gummy stem blight epidemics, we need molecular markers that can be used to consistently compare and study populations. Microsatellite markers, also known as simple sequence repeats (SSR), are ideal for our purposes because they are highly polymorphic, codominant, easy to amplify by polymerase chain reaction (PCR), work well with small quantities of DNA, and allow us to answer fine-scale questions about populations (Selkoe and Toonen 2006). Additionally, microsatellites are easy to use and interpret, can be used on very few to numerous samples, and are relatively inexpensive, especially when multiplexed (Schoebel et al. 2013), which keeps them very popular for ecological, evolutionary, and epidemiological studies (Atallah et al. 2004; Prussin et al. 2014; Rieux et al. 2011; Selkoe and Toonen 2006). Unlike RAPDs and AFLPS, microsatellite markers are species or genus specific, preventing amplification of DNA from nontarget organisms, and can be consistently compared over multiple years and among different labs (Santana et al. 2009). Next-generation sequencing methods have made development of these markers much easier, providing an abundance of putative markers at a relatively low cost (Frenkel et al. 2012; Malausa et al. 2011; Schoebel et al. 2013). Our aim is to use population genetics to provide insight about the genetic diversity and population structure of the gummy stem blight pathogens on geographically broad and fine scales to enhance epidemiological studies. The specific objectives of this study were to (i) develop microsatellite markers for the gummy stem blight pathogens, (ii) determine whether the markers can be used to distinguish the three Stagonosporopsis spp. causing gummy stem blight, (iii) determine whether worldwide populations are structured by geographic region or host, and (iv) analyze fine-scale genetic diversity and population structure of S. citrulli within watermelon fields in Georgia, United States to better understand dispersal and reproduction.

\section{MATERIALS AND METHODS}

Isolate maintenance and DNA extraction. Gummy stem blight isolates from diverse geographic locations and hosts within the Cucurbitaceae family, including watermelon (Citrullus lanatus), cucumber (Cucumis sativus), cantaloupe and muskmelon (Cucumis melo), acorn squash (Cucurbita pepo), butternut squash (Cucurbita moschata), pumpkin (Cucurbita sp.), and gourd (Cucurbita sp.), were collected for this study (Table 1). Isolates representing each of the two previously detected genetic groups (Somai et al. 2002) and three Stagonosporopsis spp. (Stewart et al. 2015) were included. An isolate of S. caricae (ATCC52577; American Type Culture Collection, Manassas, VA) from papaya (Carica papaya) was included in this study. Isolates from the United States were grown on one-quarter strength potato dextrose agar (qPDA) at $23^{\circ} \mathrm{C}$. DNA was obtained for isolates originally collected from outside the United States (Table 1). Isolates were maintained for long-term storage on filter paper at $-20^{\circ} \mathrm{C}$.

DNA was initially purified from fresh mycelium using the DNeasy Plant Mini Kit (Qiagen, Venlo, The Netherlands) following the manufacturer's instructions, and later purified by using a simplified fresh tissue extraction protocol (Milgroom et al. 2008). Briefly, a plug of mycelium was transferred to PDA overlaid with sterile cellophane. After 3 days of growth in the dark at room temperature, approximately $50 \mathrm{mg}$ fresh mycelium was harvested and added to $1 \mathrm{ml}$ of lysis buffer (50 mM EDTA [pH 8], $100 \mathrm{mM}$ Tris [pH 8], 3.5\% sodium dodecyl sulfate, proteinase $\mathrm{K}$ at $250 \mu \mathrm{g} / \mathrm{ml}$, and $1 \%$ sodium bisulfite), vortexed for $1 \mathrm{~min}$, and incubated at $65^{\circ} \mathrm{C}$ for $15 \mathrm{~min}$. Samples were vortexed briefly and centrifuged at $14,000 \times g$ for $5 \mathrm{~min}$. The supernatant was removed and added to $200 \mu \mathrm{l}$ of $7.5 \mathrm{M}$ sodium acetate, vortexed for $10 \mathrm{~s}$, placed on ice for $15 \mathrm{~min}$, and centrifuged at $14,000 \times g$ for $3 \mathrm{~min}$. The supernatant was added to $700 \mu \mathrm{l}$ of isopropanol, gently mixed to precipitate the DNA, and centrifuged at $14,000 \times g$ for $5 \mathrm{~min}$. The supernatant was discarded and the pellet was rinsed twice with $70 \%$ ethanol, dried, and resuspended in $100 \mu \mathrm{l}$ of sterile $\mathrm{H}_{2} \mathrm{O}$.

Development of microsatellite markers. Microsatellite sequences were identified using a combined microsatellite motif enrichment and next-generation sequencing approach (Malausa et al. 2011). A genomic library enriched for microsatellite motifs was developed from $S$. citrulli isolate C5-5 by hybridization to 12 biotinylated oligonucleotide repeat probes consisting of $(\mathrm{GT})_{8}$, $(\mathrm{TC})_{9.5},(\mathrm{TTC})_{7},(\mathrm{GTA})_{8.33},(\mathrm{GTG})_{4.67},(\mathrm{TCC})_{5},(\mathrm{GTT})_{6.33},(\mathrm{TTTC})_{6}$, $(\text { GATA })_{7},(\text { TTAC })_{6.75},(\text { GATG })_{4.25}$, and (TTGG) $)_{5.25}$. The library was pooled with other libraries, each with unique adapter sequences, and submitted for Roche 454 GS-FLX Titanium sequencing at the Sequencing and Genotyping Facility at the Cornell Life Sciences Core Facility (Ithaca, NY). MID-sorted 454 reads were trimmed of adapter sequences and assembled in SeqMan Pro (DNASTAR, Madison, WI). Contigs and singletons were searched for at least five perfect repeats of trimeric, tetrameric, pentameric, and hexameric microsatellites in msatcommander (Faircloth 2008). Sequences with at least 40-bp flanking sequence on each side of the repeat were considered acceptable for primer design. Primers for amplification of microsatellite loci were designed with Primer3 (Rozen and Skaletsky 2000).

Candidate microsatellite loci were evaluated on a panel of 13 isolates (marked in Table 1 by an asterisk) from the southeastern United States to ensure polymorphism in our target populations. A three-primer method (Schuelke 2000) was used in the first round of marker selection. The sequence 5'-CAGTCGGGCGTCATCA-3' (CAG tag) (Hauswaldt and Glenn 2003) was added to the $5^{\prime}$ end of the forward primer for each of the candidate microsatellite markers. The third primer consisted of the CAG tag 5' labeled with the 
fluorescent dye HEX (Integrated DNA Technologies, Coralville, IA). PCR was carried out in $12 \mu \mathrm{l}$ with $1.2 \mu \mathrm{l}$ of $10 \times$ ExTaq buffer (Takara Bio, Inc., Mountain View, CA), $1.2 \mu \mathrm{l}$ of $2.5 \mathrm{mM}$ dNTPs, $0.05 \mu \mathrm{l}$ of $10 \mu \mathrm{M} 5^{\prime} \mathrm{CAG}$ tag-labeled forward primer, $0.5 \mu \mathrm{l}$ of $10 \mu \mathrm{M}$ reverse primer, $0.5 \mu \mathrm{l}$ of $10 \mu \mathrm{M} 5^{\prime}$ HEX-labeled CAG tag primer, $0.5 \mathrm{U}$ of ExTaq (Takara Bio, Inc.), and $0.5 \mu \mathrm{l}$ of DNA template $(10$ to $100 \mathrm{ng} / \mu \mathrm{l})$. Thermal cycling conditions were $94^{\circ} \mathrm{C}$ for $2 \mathrm{~min} ; 35$ cycles of $94^{\circ} \mathrm{C}$ for $30 \mathrm{~s}, 55^{\circ} \mathrm{C}$ for $30 \mathrm{~s}$, and $72^{\circ} \mathrm{C}$ for $30 \mathrm{~s}$; followed by $72^{\circ} \mathrm{C}$ for $5 \mathrm{~min}$. Amplification of single PCR products within the expected size range was confirmed by electrophoresis on a $1 \%(\mathrm{wt} / \mathrm{vol})$ agarose gel. A 1:10 dilution of the PCR products $(1 \mu \mathrm{l})$ was mixed with $0.5 \mu \mathrm{l}$ of ROX-labeled size standard (Georgia Genomics Facility, Athens, GA) and $9.5 \mu \mathrm{l}$ of Hi-Di formamide (Applied Biosystems, Foster City, CA). Products were denatured by incubation at $95^{\circ} \mathrm{C}$ for 5 min and immediately placed on ice. Fragment analysis was conducted at the Georgia Genomics Facility on an Applied Biosystems 3730xl 96-capillary
DNA Analyzer. GeneMapper (v.4.0; Applied Biosystems) was used to determine allele sizes. Only primer sets that produced single peaks in the expected size range and showed polymorphism in our panel of 13 isolates were optimized for multiplex PCR. Microsatellite marker sequences for isolate C5-5 were deposited in GenBank under accession numbers KM364537 to KM364556 for Db01 to $D b 20$, respectively.

The forward primers of the microsatellite markers selected for multiplex PCR (Table 2) were labeled at the $5^{\prime}$ end with one of the following fluorescent dyes: 6FAM (Integrated DNA Technologies), VIC, PET, or NED (Applied Biosystems). Multiplex reactions were optimized so that loci with alleles of similar size ranges were labeled with different dyes. The multiplex reactions were tested on the panel of 13 isolates as well as 33 additional isolates from the United States, Canada, Sweden, The Netherlands, Greece, Israel, and China. Multiplex PCR was carried out using a Type-it Microsatellite PCR Kit (Qiagen) following the manufacturer's

TABLE 1. Origin and species of gummy stem blight isolates

\begin{tabular}{|c|c|c|c|c|c|}
\hline Region $^{\mathrm{a}}$ & Location & Original host species & Isolate name ${ }^{b}$ & Source $^{c}$ & Stagonosporopsis spp. ${ }^{\mathrm{d}}$ \\
\hline SE USA & Tift County, GA & Citrullus lanatus (watermelon) & C5-1* & K.S. & citrulli \\
\hline SE USA & Tift County, GA & C. lanatus (watermelon) & $\mathrm{C} 5-5^{*}$ & K.S. & citrulli \\
\hline SE USA & Tattnall County, GA & C. lanatus (watermelon) & UR4-1* & K.S. & citrulli \\
\hline SE USA & Collier County, FL & C. lanatus (watermelon) & 09-090-1* & K.S. & citrulli \\
\hline SE USA & Suwanee County, FL & C. lanatus (watermelon) & PDC-6* & K.S. & citrulli \\
\hline SE USA & Suwanee County, FL & C. lanatus (watermelon) & PDC-2 & K.S. & citrulli \\
\hline SE USA & Sampson County, NC & C. lanatus (watermelon) & $\mathrm{NCA}-4 *$ & K.S. & citrulli \\
\hline SE USA & Sampson County, NC & C. lanatus (watermelon) & $\mathrm{NC} 10-7^{*}$ & K.S. & citrulli \\
\hline SE USA & Sampson County, NC & C. lanatus (watermelon) & NC10-15* & K.S. & citrulli \\
\hline SE USA & Charleston County, SC & C. lanatus (watermelon) & $\mathrm{SC} 4-3^{*}$ & K.S. & citrulli \\
\hline SE USA & Charleston County, SC & C. lanatus (watermelon) & SC4-5 & K.S. & citrulli \\
\hline SE USA & Charleston County, SC & C. lanatus (watermelon) & SC4-10 & K.S. & citrulli \\
\hline SE USA & Alamo, TX & C. lanatus (watermelon) & RD7 & A.K. & citrulli \\
\hline SE USA & Colquitt County, GA & Cucumis sativus (cucumber) & GC-7* & K.S. & citrulli \\
\hline SE USA & Colquitt County, GA & C. sativus (cucumber) & GC-14* & K.S. & citrulli \\
\hline SE USA & Edisto, SC & C. sativus (cucumber) & C68 & A.K. & citrulli \\
\hline SE USA & Tift County, GA & C. melo (cantaloupe) & GS5-17* & K.S. & citrulli \\
\hline SE USA & Tift County, GA & C. melo (canteloupe) & GS7-1* & K.S. & citrulli \\
\hline SE USA & Oklahoma & C. melo (canteloupe) & $\mathrm{RB} 2$ & A.K. & citrulli \\
\hline SE USA & Pharr, TX & C. melo (canteloupe) & RD6 & A.K. & citrulli \\
\hline SE USA & Johnson County, NC & Cucurbita pepo (acorn squash) & AcSq5 & A.K. & citrulli \\
\hline NE USA & Sussex County, DE & Citrullus lanatus (watermelon) & RJ6 & A.K. & citrulli \\
\hline NE USA & Knox County, IN & C. lanatus (watermelon) & RT1 & A.K. & citrulli \\
\hline NE USA & Wicimico, MD & C. lanatus (watermelon) & RJ1 & A.K. & citrulli \\
\hline NE USA & New York & C. lanatus (watermelon) & GSB29 & A.K. & cucurbitacearum \\
\hline NE USA & Michigan & Cucumis sativus (cucumber) & C166 & A.K. & caricae \\
\hline NE USA & Tompkins County, NY & C. sativus (cucumber) & GSB19 & A.K. & cucurbitacearum \\
\hline NE USA & Onondaga County, NY & C. melo (muskmelon) & DIDYNY1 & A.K. & citrulli \\
\hline NE USA & Knox County, IN & C. melo (muskmelon) & RT4 & A.K. & citrulli \\
\hline NE USA & Tompkins County NY & C. melo (muskmelon) & GSB26 & A.K. & cucurbitacearum \\
\hline NE USA & Michigan & Cucurbita moschata (butternut squash) & RT2 & A.K. & cucurbitacearum \\
\hline NE USA & Montgomery County, NY & C. moschata (butternut squash) & GSB5 & A.K. & cucurbitacearum \\
\hline NE USA & Ontario County, NY & Cucurbita sp. (pumpkin) & GSB21 & A.K. & cucurbitacearum \\
\hline NE USA & Indiana & Cucurbita sp. (decorative gourd) & RU1 & A.K. & cucurbitacearum \\
\hline California & Greenhouse & Citrullus lanatus (watermelon) & RG3 & A.K. & caricae \\
\hline Other region & China & C. lanatus (watermelon) & W85 & A.K. & citrulli \\
\hline Other region & China & C. lanatus (watermelon) & W87 & A.K. & citrulli \\
\hline Other region & The Netherlands & Cucumis sativus (cucumber) & RV1 & A.K. & citrulli \\
\hline Other region & Sweden & C. sativus (cucumber) & RV2 & A.K. & citrulli \\
\hline Other region & Canada & C. sativus (cucumber) & RV16 & A.K. & caricae \\
\hline Other region & Israel & C. melo (muskmelon) & ID1 & A.K. & citrulli \\
\hline Other region & Greece & C. sativus (cucumber) & RV3 & A.K. & citrulli \\
\hline Other region & Greece & C. sativus (cucumber) & RV7 & A.K. & citrulli \\
\hline Other region & Greece & C. sativus (cucumber) & RV8 & A.K. & citrulli \\
\hline Other region & Greece & C. sativus (cucumber) & RV9 & A.K. & citrulli \\
\hline Other region & Greece & C. sativus (cucumber) & RV10 & A.K. & citrulli \\
\hline
\end{tabular}

${ }^{a}$ Regional designations used to group isolates by the geographic location of original collection include southeastern United States (SE USA), northeastern United States (NE USA), California, or a region outside of the United States (other region).

b DNA was provided for isolates from regions outside of the United States. Isolates followed by an asterisk (*) were included in the original panel used to evaluate candidate microsatellite loci.

${ }^{c}$ Isolates or DNA were kindly provided by Dr. Katherine Stevenson (K.S.), Department of Plant Pathology, University of Georgia, Tifton; or Dr. Anthony Keinath (A.K.), Coastal Research and Education Center, Clemson University, Charleston, SC.

${ }^{d}$ Isolate assignment to one of the three Stagonosporopsis spp. that cause gummy stem blight as described previously (Stewart et al. 2015). The species epithet is listed for each isolate. 
instructions, except that reactions were scaled to $10 \mu \mathrm{l}$. Each of the three multiplex reactions consisted of $5 \mu \mathrm{l}$ of $2 \times$ Type-it Master Mix, $1 \mu \mathrm{l}$ of $10 \times$ primer mix (which consisted of $2 \mu \mathrm{M}$ each primer in the multiplex), $1 \mu \mathrm{l}$ of DNA template (10 to $100 \mathrm{ng} / \mu \mathrm{l}$ ), and RNAse-free water. Thermal cycling conditions were $95^{\circ} \mathrm{C}$ for $5 \mathrm{~min} ; 28$ cycles of $95^{\circ} \mathrm{C}$ for $30 \mathrm{~s}, 57^{\circ} \mathrm{C}$ for $90 \mathrm{~s}$, and $72^{\circ} \mathrm{C}$ for $30 \mathrm{~s}$; followed by $60^{\circ} \mathrm{C}$ for 30 min. PCR products were diluted 1:15 in double-distilled $\mathrm{H}_{2} \mathrm{O}$ and $1 \mu \mathrm{l}$ of diluted PCR product was combined with $0.1 \mu \mathrm{l}$ of the internal size standard Genescan-500 Liz (Applied Biosystems) and $9.9 \mu \mathrm{l}$ of Hi-Di formamide (Applied Biosystems). Samples were incubated at $95^{\circ} \mathrm{C}$ for $5 \mathrm{~min}$ and placed immediately on ice, and fragment analysis was carried out at the Georgia Genomics Facility, as described above. Genemapper v.4.0 was used to score alleles. Loci were distinguished by fluorescent dye and allele size range.

The number of alleles and unbiased gene diversity $(h)$ for each microsatellite locus was estimated with Genalex v.6.41 (Peakall and Smouse 2006). Genetic differentiation $\left(\Phi_{\mathrm{PT}}\right.$, an analog of $G_{\mathrm{ST}}$ measured via analysis of molecular variance [AMOVA]) (Peakall et al. 1995) among geographic regions and host species was estimated using GenAlEx v.6.41 on clone-corrected data sets, which included only one representative of each unique multilocus genotype. Significant differentiation between populations was determined by comparing observed values to the distribution of 1,000 randomizations of the data. In order to visualize major patterns of variation within and among populations from different geographic regions and hosts, principal coordinates analysis (PCA) was conducted with GenAlEx v.6.41 on pairwise genetic distances of all genotypes. Genotypic diversity $(\hat{G})$ (the probability that two individuals taken at random have unique multilocus genotypes) or $[N /(N-1)]\left(1-\Sigma p_{\mathrm{i}}^{2}\right)$, where $p_{\mathrm{i}}$ is the frequency of the $i$ th multilocus genotype and $N$ is the sample size for each population, was estimated in MultiLocus v.1.3b (Agapow and Burt 2001). Multilocus linkage disequilibrium was determined for the clonecorrected dataset using the index of association $\left(I_{\mathrm{A}}\right)$ (Smith et al. 1993) estimated with MultiLocus v.1.3b: $I_{\mathrm{A}}=s_{\mathrm{k}}{ }^{2} / \sigma_{\mathrm{k}}{ }^{2}-1$, where $k$ is the number of loci at which pairs of individuals have different alleles, $s_{\mathrm{k}}^{2}$ is the observed variance of $k$, and $\sigma_{\mathrm{k}}{ }^{2}$ is the expected variance of $k$ under linkage equilibrium. $I_{\mathrm{A}}$ is not significantly different from zero when the population is in linkage equilibrium. $P$ values were estimated by 1,000 random permutations of the data.

TABLE 2. Repeat motif, primer sequences, multiplexing primers and reactions, allele sizes and number, and gene diversity (h) for Stagonosporopsis citrulli microsatellite loci

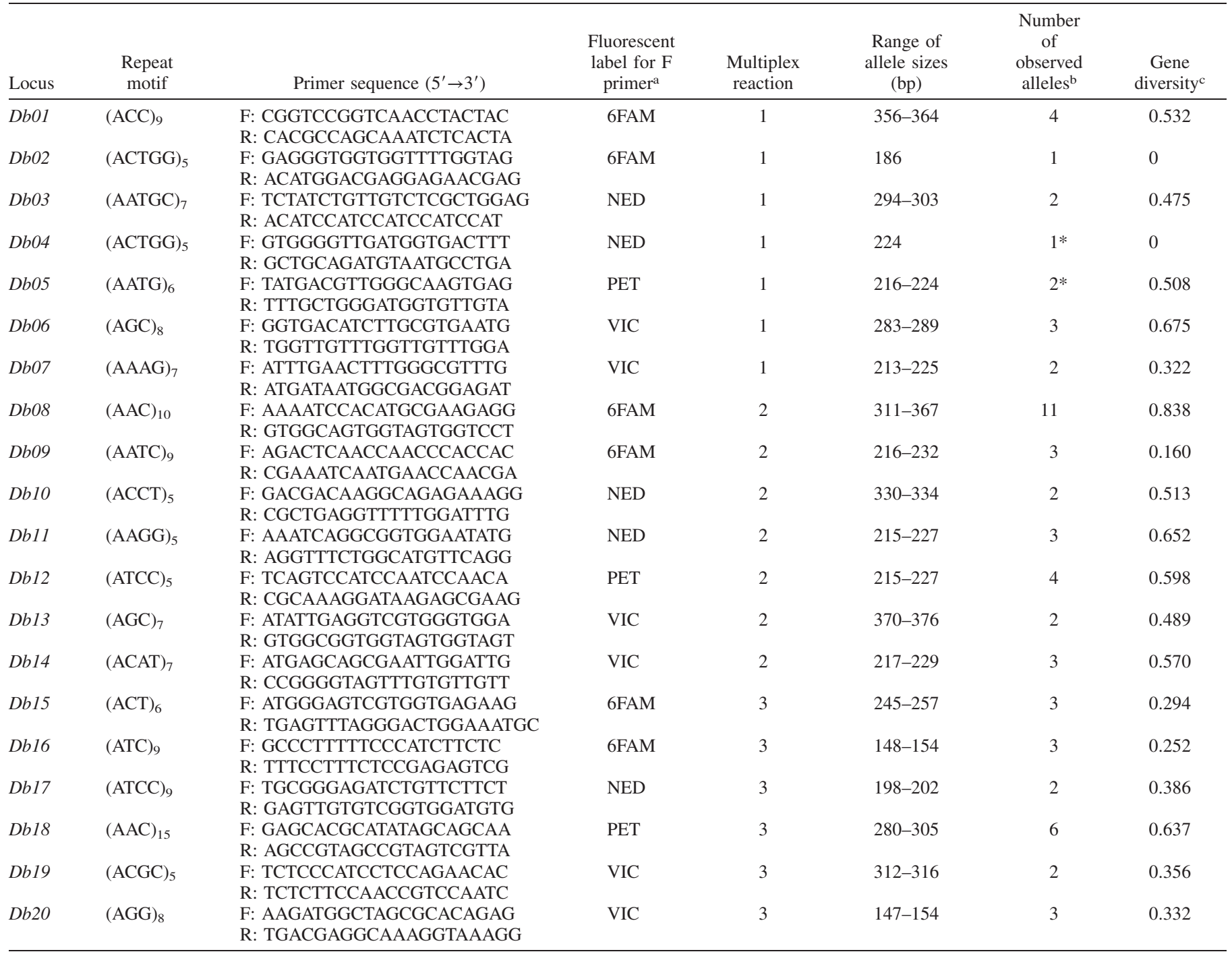

${ }^{a}$ Fluorescent primers allowed for visualization on ABI3730 DNA Analyzer and cost-effective, efficient polymerase chain reaction (PCR) multiplexing.

b Number of alleles listed is for S. citrulli. The asterisks indicate where additional alleles were consistently observed for all three species. For $\mathrm{Db04}$, alleles of 196 , 199, and $202 \mathrm{bp}$ were detected for S. cucurbitacearum isolates and an allele of $191 \mathrm{bp}$ was detected for $S$. caricae isolates. For Db05, alleles of 216 and 220 bp were detected for S. cucurbitacearum isolates and alleles of 216 and 218 bp were detected for S. caricae isolates. Db06 and Db07 could be PCR amplified for S. cucurbitacearum (allele sizes of $191 \mathrm{bp}$ and 218 or 216 bp, respectively) and Db11 could be PCR amplified for S. caricae (allele sizes of 221, 226, or 232 bp).

${ }^{c}$ Unbiased gene diversity estimated by GenAlEx v.6.41 (Peakall and Smouse 2006). 
Bayesian cluster analysis, a powerful method for identifying population structure and assigning individuals to populations (Pritchard et al. 2000), was not used in this study because linkage disequilibrium among loci within populations, likely due to nonrandom mating of $S$. citrulli from selfing, violates the assumptions of this type of analysis.

Comparison of microsatellite loci across lineages. Although all microsatellite loci were consistently amplified from isolates of $S$. citrulli, only 2 of the 20 microsatellite loci were amplified in isolates from all three closely related Stagonosporopsis spp. that cause gummy stem blight. To compare sequences among isolates and determine whether homologous regions were amplified across the three species, alleles of the two loci ( $\mathrm{Db04}$ and $\mathrm{Db05}$ ) were sequenced for 17 isolates, including 9 isolates from $S$. citrulli, 5 isolates from $S$. cucurbitacearum, and 3 isolates from $S$. caricae. The PCRs were carried out in a total volume of $25 \mu \mathrm{l}$. Reaction components included $2.5 \mu \mathrm{l}$ of $10 \times$ PCR buffer (Takara Bio, Inc.), $2.5 \mu \mathrm{l}$ of dNTPs, $1.25 \mu \mathrm{l}$ of $10 \mu \mathrm{M}$ forward and reverse primers, $0.15 \mu \mathrm{l}$ of ExTaq (Takara Bio, Inc.), and $1 \mu \mathrm{l}$ of DNA template. Cycling conditions included an initial denaturation step at $94^{\circ} \mathrm{C}$ for $2 \mathrm{~min}$; followed by 35 cycles with a denaturation step at $94^{\circ} \mathrm{C}$ for $30 \mathrm{~s}$, annealing at $55^{\circ} \mathrm{C}$ for $30 \mathrm{~s}$, and extension at $72^{\circ} \mathrm{C}$ for $30 \mathrm{~s}$; followed by a final extension at $72^{\circ} \mathrm{C}$ for $5 \mathrm{~min}$. Amplification of single PCR products within the expected size range was confirmed by electrophoresis on a $1 \%(\mathrm{wt} / \mathrm{vol})$ agarose gel. PCR products were purified with QIAquick spin columns (Qiagen). Sequencing was conducted at the Georgia Genomics Facility of the University of Georgia using the Applied Biosystems Automated 3730 DNA Analyzer with Big Dye Terminator chemistry and Ampli-Taq-FS DNA Polymerase. All gene regions were sequenced in both directions with forward and reverse primers. Sequences were aligned and manually edited as needed in Geneious (v.6; Biomatters Ltd., Auckland, New Zealand). Alignments were deposited in TreeBASE under accession numbers 16262 and 16261 for Db04 and Db05, respectively. Phylogenies were reconstructed by maximum likelihood in MEGA5 (Tamura et al. 2011). The HasegawaKishino-Yano and Kimura 2-parameter models of evolution for $\mathrm{Db04}$ and $\mathrm{Db05}$, respectively, as determined most appropriate in MEGA5, were implemented. Support for internal branches was determined by 500 bootstrap replicates.

PCR-based marker for detecting lineages. A rapid PCRbased assay for distinguishing the three morphologically similar species was developed using three microsatellite markers in a single reaction, including $\mathrm{DbO1}$ that amplifies a fragment only from isolates of $S$. citrulli, Db06 that amplifies a fragment only from isolates of S. citrulli or $S$. cucurbitacearum, and Db05 that amplifies a fragment from isolates from all three species. Three isolates from each species were used to test the marker, including C5-5, UR4-1, and DIDYNY from S. citrulli; RT2, GSB26, and GSB5 from S. cucurbitacearum; and RG3, C166, and ATCC52577 from S. caricae. Two additional isolates from Alternaria and Phoma spp. (Keinath et al. 1995), which are similar in colony morphology to gummy stem blight isolates and are frequently isolated from symptomatic cucurbits, were included to determine whether bands were specific for the Stagonosporopsis isolates. The PCR reactions were carried out in a total volume of $25 \mu \mathrm{l}$. Reaction components included $2.5 \mu \mathrm{l}$ of $10 \times$ PCR buffer (Takara Bio, Inc.), $2.5 \mu \mathrm{l}$ of dNTPs, $1.25 \mu \mathrm{l}$ of $10 \mu \mathrm{M}$ forward and reverse primers for each of the three loci ( $D b 01, D b 05$, and $D b 06$ ) (Table 2), $0.15 \mu \mathrm{l}$ of ExTaq (Takara Bio, Inc.), and $1 \mu \mathrm{l}$ of DNA template. Cycling conditions were the same as for the microsatellite sequencing reaction. Electrophoresis of PCR products was conducted on a $2.5 \%(\mathrm{wt} / \mathrm{vol})$ agarose gel run at $95 \mathrm{~V}(4.75 \mathrm{~V} / \mathrm{cm})$ for $3.5 \mathrm{~h}$. DNA was visualized with $500 \times$ GelRed (Biotium, Hayward, CA) added prior to gel casting.

Diversity and population structure in field populations. To understand fine-scale population genetic structure and diversity of $S$. citrulli and to test the utility of the microsatellite markers in southeastern United States field populations, 200 leaves from watermelon plants with lesions characteristic of gummy stem blight were collected arbitrarily at distances of 5 to $20 \mathrm{~m}$ apart in July 2012 from two fields in Tift County, GA and Cook County, GA. The two fields were separated by $20 \mathrm{~km}$. Isolates of $S$. citrulli were obtained from surface-disinfested leaves by soaking a $1-\mathrm{cm}^{2}$ segment of a leaf containing the margin of a lesion for $1.5 \mathrm{~min}$ in $0.6 \%$ sodium hypochlorite and rinsing twice with sterile distilled water. Three cuttings per leaf were placed on a $100-\mathrm{mm}$ petri dish of qPDA. After 3 days of growth at $25^{\circ} \mathrm{C}$, a 4-mm² agar segment containing hyphal tips was transferred to a fresh dish of qPDA. Identity as a Stagonosporopsis sp. was initially confirmed by growth rate and colony morphology. Isolates were maintained for long-term storage on filter paper at $-20^{\circ} \mathrm{C}$. DNA was extracted using the protocol described above (in the section "Isolate maintenance and DNA extraction") (Milgroom et al. 2008). All isolates were genotyped with the 20 microsatellite markers using three multiplex reactions carried out with the Type-it Microsatellite PCR Kit (Qiagen), as described above.

For each of the two populations, genotypic diversity $(\hat{G})$ was estimated in MultiLocus v.1.3b (Agapow and Burt 2001). Multilocus linkage disequilibrium, a measure of nonrandom mating, was determined for the clone-corrected dataset using the $I_{\mathrm{A}}$ (Smith et al. 1993) estimated with MultiLocus v.1.3b. $P$ values were estimated by 1,000 random permutations of the data. Recombination events were detected using the four-gamete test (Hudson and Kaplan 1985) on pairs of microsatellite loci. Measured via AMOVA, $\Phi_{\mathrm{PT}}$ Peakall et al. 1995 ) between the field populations was estimated using GenAlEx v.6.41 on full and clone-corrected data sets. Significant differentiation between field populations was determined by comparing observed values to the distribution of 1,000 randomizations of the data. PCA was conducted with GenAlEx v.6.41 on pairwise genetic distances of all genotypes in order to visualize major patterns of variation within and between the two populations. The power of the microsatellite loci to resolve genotypes was tested by plotting the proportion of genotypes recovered against the number of loci analyzed with 1,000 randomizations of the data in MultiLocus v.1.3b.

\section{RESULTS}

Microsatellite loci. In total, 102,497 contigs and singletons were obtained from 210,507 reads, resulting in $34 \mathrm{Mb}$ of unique sequence. In all, 22,705 of the contigs fit our criteria for development as microsatellite markers. Sixty-eight sets of primers were designed and tested for PCR amplification. Fifty-four sets (80\%) amplified a single product and were visible on an agarose gel. In all, 29 sets consistently produced a single, well-defined peak during fragment analysis on the ABI DNA Analyzer, and 18 sets were polymorphic across the panel of 13 isolates. Although they were not polymorphic among the 13 isolates tested, two additional loci were added to the reactions because they appeared to be polymorphic among the other Stagonosporopsis spp. The robust primer sets were organized into three multiplex reactions by using four different dyes and combining loci of distinct allele sizes with the same dye (Table 2). Multiplex reactions 1 and 2 each consist of seven loci and reaction 3 consists of six loci. The multiplex reactions worked consistently for template DNA, ranging from 10 to $100 \mathrm{ng} / \mu \mathrm{l}$.

For the loci that were polymorphic within $S$. citrulli, unbiased gene diversity $(h)$ ranged from 0.160 to 0.838 , and 2,3 , or 4 alleles were detected per locus, except for $D b 08$ and $D b 18$, which had 11 and 6 alleles, respectively. The locus $\mathrm{DbO2}$ was not polymorphic among isolates in this study (Table 2), and $\mathrm{Db04}$ was not polymorphic within $S$. citrulli isolates. Only $\mathrm{Db04}$ and $\mathrm{Db05}$ could be PCR amplified across all three Stagonosporopsis spp. causing gummy stem blight. For Db04, alleles of 196, 199, and 202 bp were detected for $S$. cucurbitacearum isolates and an allele of $191 \mathrm{bp}$ was detected for $S$. caricae isolates. For Db05, alleles of 216 and $220 \mathrm{bp}$ were detected for $S$. cucurbitacearum isolates, and alleles of 216 and 218 bp were detected for $S$. caricae isolates. Db06 and Db07 could be PCR amplified for $S$. cucurbitacearum (allele sizes of $191 \mathrm{bp}$ and 218 or $216 \mathrm{bp}$, respectively) and Db11 could be PCR amplified for $S$. caricae (allele sizes of 221, 226, or $232 \mathrm{bp}$ ). 
Of the 46 isolates from diverse geographic regions and host plants, and the three Stagonosporopsis spp. (Stewart et al. 2015), only the 36 isolates that belonged to $S$. citrulli consistently amplified across all of the loci; therefore, population genetic analyses could only be conducted on isolates from this species. Among the 36 isolates, there were 30 unique multilocus genotypes, 3 of which were represented by 2 or more isolates. The three repeated genotypes included one consisting of three isolates from watermelon from South Carolina (SC4-3, SC4-5, and SC4-10), one consisting of two isolates from watermelon from China (W85 and W87), and one consisting of four isolates from Europe (three from Greece and one from the Netherlands) on cucumber (RV1, RV8, RV9, and RV10). All other isolates had unique genotypes. No clustering by hosts or region was observed by PCA (Fig. 1). Although sample sizes were small, there was no partitioning of genetic diversity by host (watermelon $[n=15] \times$ cucumber $[n=7] \times$ muskmelon/cantaloupe $\left.[n=7], \Phi_{\mathrm{PT}}=0.009, P=0.325\right)$ or region (southeastern United States $[n=19] \times$ northeastern United States $[n=5] \times$ other region $\left.[n=6], \Phi_{\mathrm{PT}}=0.009, P=0.327\right)$ on the clone-corrected dataset. Although three clonal genotypes were detected, genotypic diversity was relatively high $(\hat{G}=0.984)$. However, nonrandom mating was detected even after clone correction for repeated genotypes $\left(I_{\mathrm{A}}=0.694, P<0.001\right)$.

To compare the two microsatellite loci that amplified for all three species to determine whether allele size differences were due to variation in repeat length and gain insight into variation within and among the three Stagonosporopsis spp. at these loci, we sequenced $D b 04$ and $D b 05$ for a select set of 17 isolates (Fig. 2). For both loci, the sequences were identical or nearly identical within species yet they were extremely divergent among species, providing 99 to $100 \%$ bootstrap support for each species. For the 205-nucleotide (nt) alignment of Db05 (Fig. 2A), S. cucurbitacearum differed from

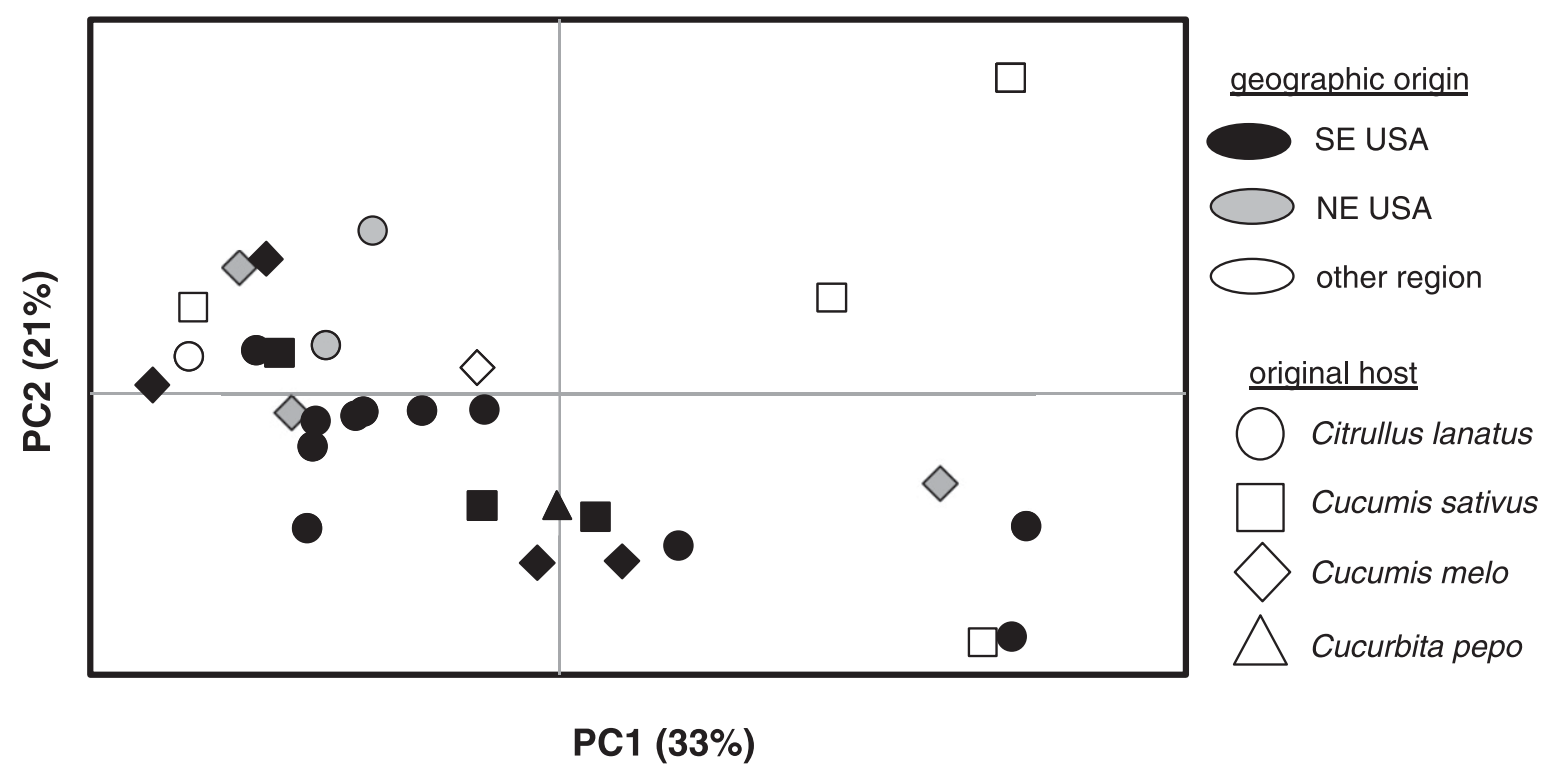

Fig. 1. Principal coordinates analysis of pairwise genetic distances of multilocus genotypes of 36 isolates of Stagonosporopsis citrulli from diverse cucurbit hosts and geographic regions. The first two principal coordinates, PC1 and PC2, are shown. Multilocus genotypes were based on alleles at 18 polymorphic microsatellite loci (Db01, Db03, and $\mathrm{Db05}$ to $\mathrm{Db20}$ ). Population assignment of each isolate based on geographic origin (southeast United States [SE USA], northeastern United States [NE USA], or other region) is indicated by the color of the data point, whereas original host (Citrullus lanatus [watermelon], Cucumis sativus [cucumber], C. melo [cantaloupe or muskmelon], or Cucurbita pepo [squash or gourd]) is indicated by the shape of the data point, as shown in the key.

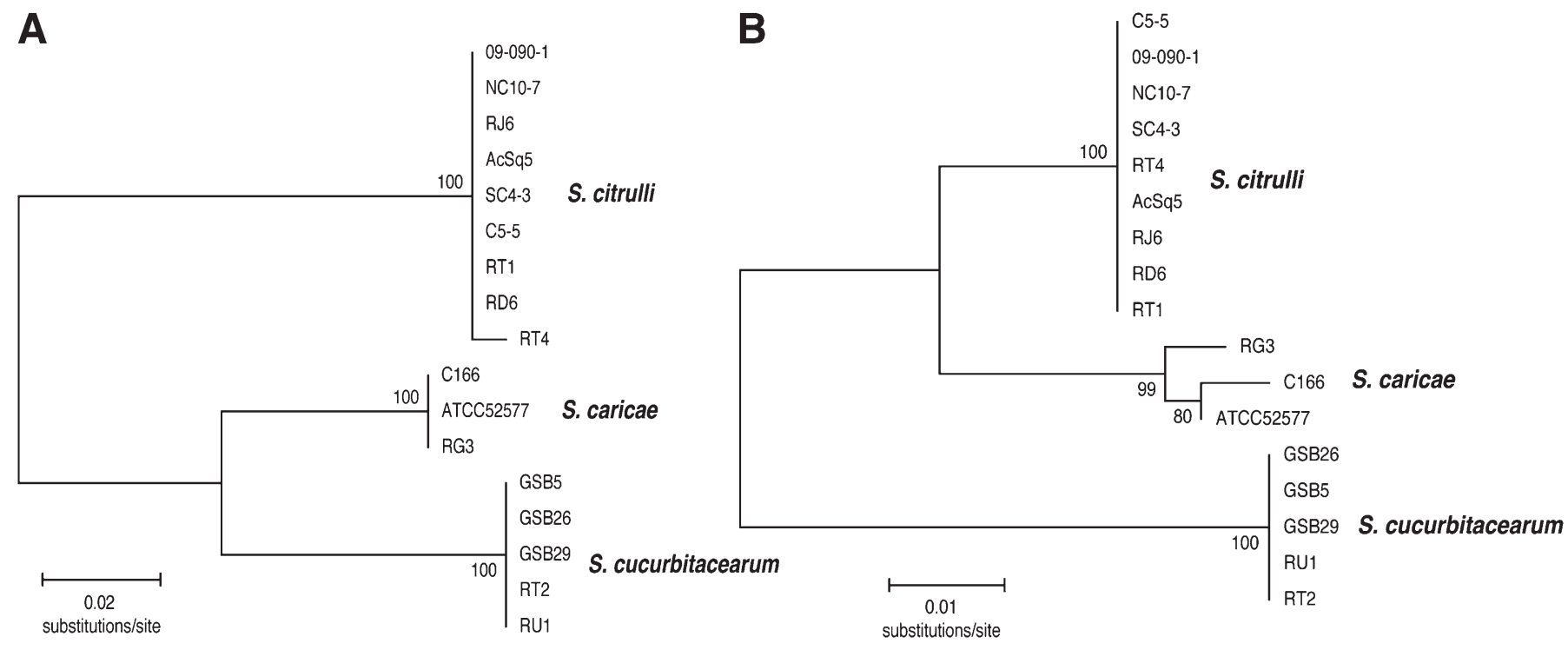

Fig. 2. Maximum likelihood trees of the loci $\mathbf{A}, D b 05$ and $\mathbf{B}, D b 04$. Both loci were sequenced and aligned for 17 isolates representing the three species of Stagonosporopsis causing gummy stem blight. All isolates were originally collected from cucurbit hosts, except ATCC52577, which was originally isolated from papaya in Hawaii. The original host and geographic origin of each cucurbit isolate is listed in Table 1. Bootstrap support for each clade is shown. 
S. citrulli by 23 single nucleotide polymorphisms (SNPs) and 5 insertion/deletions (indels) at regions other than the microsatellite region, and $S$. caricae differed from $S$. citrulli by 18 SNPs and 6 indels at regions other than the microsatellite repeat. There was one SNP and an indel in the microsatellite repeat region within $S$. citrulli isolates, one indel within $S$. cucurbitacearum isolates, and no variation within $S$. caricae isolates. For the 206-nt alignment of Db04 (Fig. 2B), $S$. cucurbitacearum differed from $S$. citrulli by 6 SNPs and one large indel, and $S$. caricae differed from $S$. citrulli by 14 SNPs and the same large indel. There was no variation within $S$. citrulli isolates, two SNPs and one indel within $S$. cucurbitacearum isolates, and one indel within $S$. caricae isolates.

PCR-based marker for distinguishing the three species causing gummy stem blight. The marker (Fig. 3) was designed using three sets of primers, including $\mathrm{Db} 05$ that produces a 216- to 224-bp fragment in all three species, Db06 that produces a 283- to 289-bp fragment in S. citrulli and a 268-bp and slightly fainter fragment in S. cucurbitacearum, and $\mathrm{DbO1}$ that produces a $356-$ to 364-bp fragment in S. citrulli. The size and number of fragments correlated perfectly with the previously determined species (Stewart et al. 2015). The isolates of Alternaria and Phoma spp. did not amplify.

Diversity and population structure in field populations. To evaluate diversity and population structure and to test the microsatellite markers on field populations in the southeastern United States, we genotyped 83 and 72 isolates from two watermelon fields in Tift County, GA and Cook County, GA, respectively (Table 3). One hundred symptomatic leaves were collected from each field but gummy stem blight isolates were not recovered from all leaves due to secondary fungi and contamination. All Stagonosporopsis isolates were identified as $S$. citrulli based on amplification and allele size of microsatellite loci. Genotypic diversity of 0.904 and 0.926 for Tift County and Cook County, respectively, was relatively high, even though 47 and $51 \%$ of the isolates did not have unique genotypes. Twelve repeated genotypes, considered as clones, were present in the Tift County field and nine clones were present in the Cook County field. Each field contained a different dominant clone that included 19 and 17 individuals for Tift County and Cook County, respectively. Four clones were present in both of the fields, including one clone represented by a single isolate from each field, two clones with a single isolate from Tift County and 3 or 5 isolates from Cook County, and one clone represented by 2 isolates from Tift County and 17 isolates from Cook County. Nonrandom mating $\left(I_{\mathrm{A}}\right)$ was detected within each field, even after clone correction. However, recombination events were detected using the four-gamete test (Hudson and Kaplan 1985) on the loci $D b 01, D b 03$, and $D b 05$, which each contained two alleles (Db01: 356/364 bp, Db03: 294/303 bp, and Db05: 224/216 bp) within the field populations. All four combinations of alleles for $\mathrm{DbO1}$ and $\mathrm{Db03}, \mathrm{DbO3}$ and $\mathrm{Db05}$, and $\mathrm{DbO1}$ and $\mathrm{Db} 05$ were detected among isolates within the populations.

Although they shared clones, populations of S. citrulli from the two watermelon fields in Georgia were genetically structured. There was overlap among the genotypic profiles of isolates from the two fields (Fig. 4); however, subtle differences in the clustering of isolates can be observed and values of PC1 and PC2 are significantly different between fields (equal variance, two-tailed $t$ test, $P<0.001$ for both PC1 and PC2). Genetic differentiation between fields was detected on both the entire $\left(\Phi_{\mathrm{PT}}=0.086, P<0.001\right)$ and clone-corrected $\left(\Phi_{\mathrm{PT}}=0.019, P=0.024\right)$ datasets.

To determine whether fewer than 18 loci would be sufficient for distinguishing genotypes from the two field populations, we plotted the proportion of genotypes identified against the number of loci analyzed (Fig. 5). With 7 loci, 50\% of the genotypes could be identified; yet, with 15 loci, $95 \%$ of the genotypes could be identified. Eighteen loci appear to be sufficient for resolution of the total number of unique genotypes because the data are nearing a plateau; however, one or two additional polymorphic loci could lead to the identification of additional genotypes in these populations.

\section{DISCUSSION}

To characterize the genetic diversity and population structure of gummy stem blight fungi, particularly in the southeastern United States, to provide insight into the epidemiology of this disease, we developed 20 microsatellite markers using a method that combines microsatellite repeat enrichment and next-generation sequencing (Malausa et al. 2011). During the development of these markers, it was discovered that gummy stem blight of cucurbits is caused by three distinct species: $S$. caricae, S. cucurbitacearum, and S. citrulli (Stewart et al. 2015). S. caricae had been described as

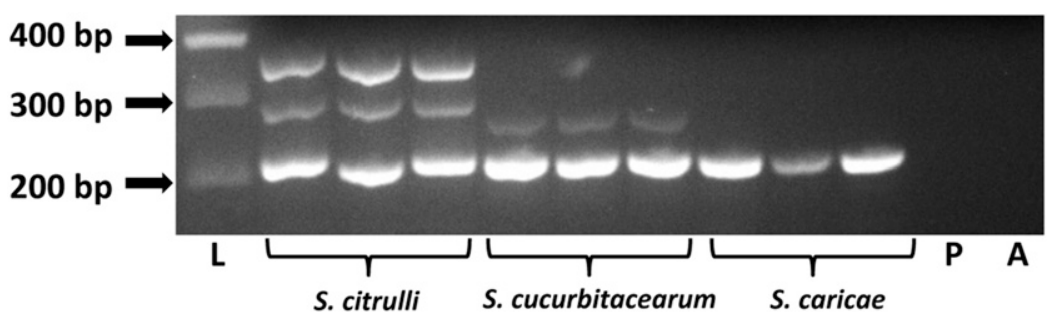

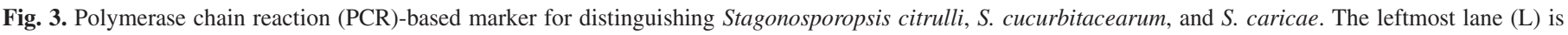

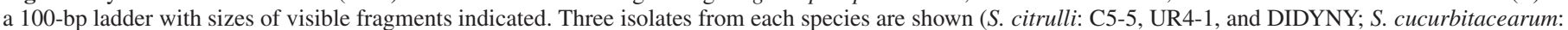

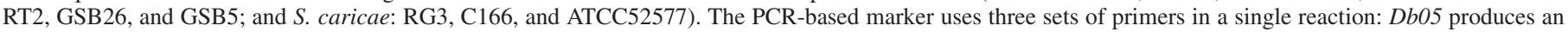

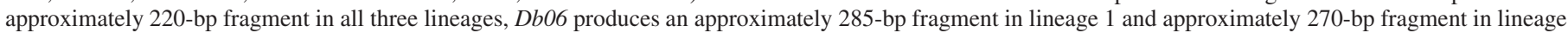

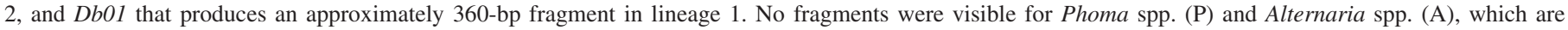
vaguely similar to Stagonosporopsis spp. in colony morphology and are frequently recovered from symptomatic plants.

TABLE 3. Genetic diversity and linkage disequilibrium in field populations of Stagonosporopsis citrulli causing gummy stem blight

\begin{tabular}{|c|c|c|c|c|c|c|c|}
\hline Population & Sample size $(N)$ & $\begin{array}{l}\text { Number of } \\
\text { genotypes }(g)\end{array}$ & $\begin{array}{l}\text { Repeated } \\
\text { fraction }^{\mathrm{a}}\end{array}$ & $\begin{array}{l}\text { Genotypic } \\
\text { diversity }\end{array}$ & $\begin{array}{l}\text { Number of } \\
\text { repeated genotypes }\end{array}$ & $\begin{array}{l}\text { Number of isolates in each } \\
\text { repeated genotype }\end{array}$ & $I_{\mathrm{A}}(P \text { value })^{\mathrm{c}}$ \\
\hline Tift County, GA & 83 & 44 & 0.47 & 0.904 & 12 & $19,5,4,4,3,3,3,2,2,2,2,2$ & $0.881(<0.001)$ \\
\hline Cook County, GA & 72 & 40 & 0.51 & 0.926 & 9 & $17,5,4,4,3,2,2,2,2$ & $0.271(0.024)$ \\
\hline
\end{tabular}

a Repeated fraction $=1-(g / N)$.

b Genotypic diversity $=[N /(N-1)]\left(1-\Sigma p_{i}{ }^{2}\right)$, where $p_{i}$ is the frequency of the $i$ th genotype.

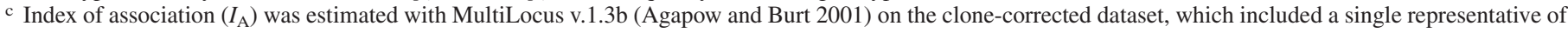
each multilocus genotype. $P$ values were determined by 1,000 randomizations. 
a papaya pathogen and S. cucurbitacearum (syn. D. bryoniae) was found to consist of two morphologically similar but phylogenetically distinct lineages; therefore, S. citrulli was erected to encompass one of the species. Of the 20 loci developed, 18 were polymorphic within S. citrulli, which is the most common and widespread of the three Stagonosporopsis spp. that cause gummy stem blight (Stewart et al. 2015). It is suggested for future studies not to add two markers, $\mathrm{DbO2}$ and $\mathrm{Db04}$, to the multiplex reactions, because they are not polymorphic; however, $D b 04$ is useful for comparisons across species. Although it would be advantageous to have molecular markers that PCR amplify for all three species, cross-amplification of microsatellites across species is often not possible (Barbara et al. 2007; Njambere et al. 2010; Selkoe and Toonen 2006), especially for fungi (Dutech et al. 2007). When microsatellite loci do amplify in congeneric species, they are often invariable or contain null alleles (Selkoe and Toonen 2006), both of which were issues that we experienced when using the markers on isolates from $S$. cucurbitacearum and $S$. caricae. Only two of the loci, Db04 and Db05, amplified across all three species. Except for these two loci and $D b 06$ and $D b 07$ that could be PCR amplified for $S$. cucurbitacearum and $D b 11$ that could be PCR amplified for $S$. caricae, the other loci did not amplify in $S$. cucurbitacearum or
S. caricae, which was the result of either mutation in the flanking sequence that prevented annealing of the primers or the complete absence of these loci or either flanking sequence within the other closely related species. The two loci that did PCR amplify across species were variable in allele size as a result of indels rather than changes in the number of microsatellite repeats. The loci also had numerous SNPs among lineages which, when combined with the differences in size due to indels, leads to them being problematic markers for population genetic studies due to the assumption that fragments of the same size are alleles that are identical by descent (Selkoe and Toonen 2006). The markers were robust, especially for populations within the southeastern United States, where $99 \%$ of the 600 cucurbit gummy stem blight isolates we genotyped to date (data not shown) belong to S. citrulli. The other $1 \%$ (four isolates) of isolates we genotyped from the southeastern United States belong to $S$. caricae and were all obtained from a single watermelon field in Tift County, GA in 2013. Overall, these new microsatellite markers were reproducible and inexpensive, especially when multiplexed, and will be used in future studies aimed at answering epidemiological questions.

When tested on 46 isolates from diverse cucurbit hosts and regions around the world, the markers were consistent and repeatable for

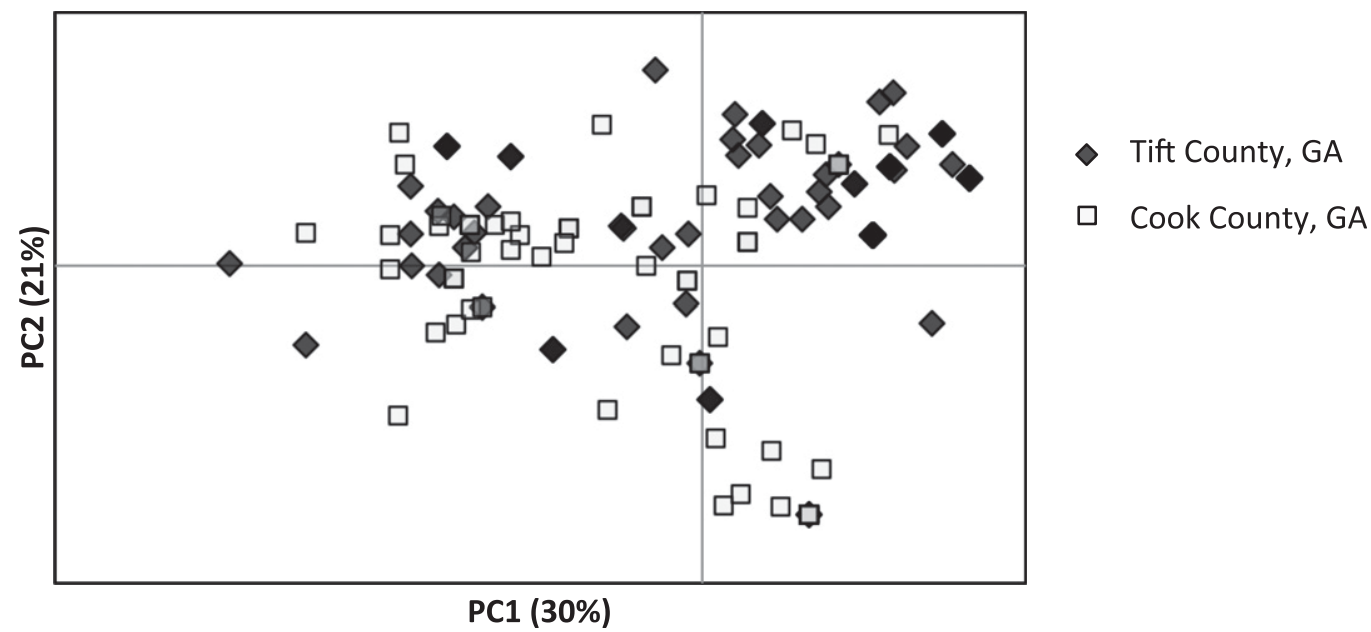

Fig. 4. Principal coordinates analysis of pairwise genetic distances of multilocus genotypes of 155 isolates of Stagonosporopsis citrulli sampled from symptomatic watermelon (Citrullus lanatus) leaves from two field sites in Georgia. The first two principal coordinates, PC1 and PC2, are shown. Multilocus genotypes were based on alleles at 18 polymorphic microsatellite loci ( $\mathrm{Db01}, \mathrm{Db03}$, and $\mathrm{Db05}$ to $\mathrm{Db} 20$ ). The field site of each isolate (Tift County, GA or Cook County, GA) is indicated by the color and shape of the data point, as shown in the key. Overlapping of isolates from the two fields results in various shades of gray.

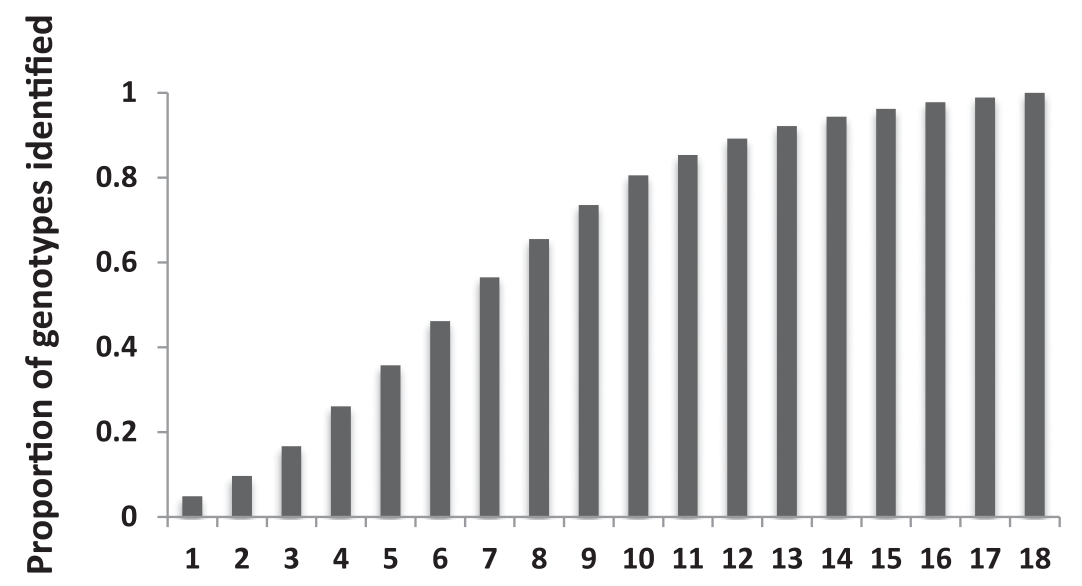

\section{Number of loci sampled}

Fig. 5. Power of the microsatellite loci to resolve genotypes of Stagonosporopsis citrulli sampled from two Georgia watermelon fields in July 2012 . The proportion of genotypes identified is plotted against the number of loci analyzed with 1,000 randomizations of the data in MultiLocus v.1.3b (Agapow and Burt 2001). 
S. citrulli. Within S. citrulli, we found no population structure based on broad-scale geographic region or host of origin, suggesting widespread dispersal around the world. This is in contrast to another homothallic fungal plant pathogen, Sclerotinia sclerotiorum, which is quite distinct on canola in different regions of the world (Attanayake et al. 2013). In our study, three clones of Stagonosporopsis citrulli were detected but each came from the same host. One clone was from watermelon in a single field in South Carolina. The second clone was represented by three isolates from watermelon in China, and the third clone was represented by four isolates from cucumber in Europe (Greece, $n=3$, and The Netherlands, $n=1$ ). It is probable that the clones in Europe were dispersed on seed. Future studies aimed at determining worldwide patterns of migration by tracking genotypes of isolates collected from cucurbit production regions using the microsatellite markers would be informative for identifying sources of inoculum for greenhouse and field epidemics.

Although differences in aggressiveness among the three species to cucurbit hosts have not been detected, they do vary in pathogenicity to papaya (Stewart et al. 2015) and could vary in fungicide resistance or reproductive biology. Therefore, it is important to be able to rapidly detect and distinguish the species to determine which are present in a particular host, field, or region. Using the microsatellite markers, we developed a PCR-based assay that discriminates the three species causing gummy stem blight of cucurbits, something that we were not able to do based on simple morphological features. This method is much simpler, cheaper, and faster than a sequence-based approach. The marker also works for $S$. caricae isolates from papaya. In future studies, the PCR-based marker can be used to determine the frequency and distribution of the three Stagonosporopsis spp. causing gummy stem blight, which is an area in need of further investigation, because the regional and worldwide distribution of the species is not well known. If $S$. citrulli represents the majority of isolates in a population of interest, the 18 polymorphic microsatellite markers would be useful for population genetic analyses.

To better understand dispersal, reproduction, and fine-scale genetic diversity of $S$. citrulli within and among watermelon fields and test the utility of the microsatellite markers on populations causing gummy stem blight within the southeastern United States, 155 isolates from two field populations in Georgia were genotyped with the 20 microsatellite loci. To our knowledge, this is the first study to investigate within-field genetic diversity of the gummy stem blight pathogen. All of the isolates from Georgia belonged to S. citrulli. Eighteen of the loci were polymorphic in these populations and were used in the population genetic analyses. Although dominant and widespread clones - inferred by identical multilocus genotypes-were detected, we found relatively high genotypic diversity and recombinant genotypes consistent with recurrent recombination. It is not clear whether the isolates with clonal genotypes resulted from homothallic sexual reproduction (selfing), asexual reproduction, or a combination of both. Abundant pycnidia (asexual reproductive structures) full of asexual spores are produced by $S$. citrulli in the field; therefore, asexual reproduction is assumed to contribute to the production of clonal genotypes. Multilocus linkage disequilibrium $\left(I_{\mathrm{A}}\right)$ within both populations even after clone correction suggests nonrandom mating that results from selfing, although other mechanisms such as epistasis or population admixture (Milgroom 1996) cannot be ruled out completely. Many self-compatible fungi are capable of outcrossing (Atallah et al. 2004; Debuchy and Turgeon 2006), which leads to increased diversity through recombination and the production of novel genotypes. To confirm that $S$. citrulli can self and outcross in nature (i.e., it has a mixed mating system), we would need to collect and genotype ascospore progeny from the pseudothecia (sexual reproductive structures) and demonstrate that some structures contain progeny with identical genotypes and some contain progeny with recombinant genotypes. This is important for understanding the epidemiology and management of gummy stem blight, because a mixed mode of reproduction with sexual recombination leads to pathogens with a high evolutionary potential (McDonald and Linde
2002), with outcrossing producing new combinations of alleles and clonal amplification by asexual reproduction or selfing propagating successful combinations (Milgroom 1996). This potential for rapid evolution could explain why isolates causing gummy stem blight are able to rapidly develop fungicide resistance (Avenot et al. 2012; Keinath 2012; Stevenson et al. 2004). The evolution of quantitative resistance likely involves multiple genes, which will evolve much faster in recombining populations where advantageous alleles can be brought together by sexual reproduction that involves some level of outcrossing. Additionally, multigene resistance to several fungicides is enhanced in a sexually recombining population.

Significant population genetic structure between the two field populations of $S$. citrulli demonstrates that this is not a panmictic population at the regional level and dispersal among fields is limited, even though structure was not detected on a worldwide scale. This difference could be from the increased statistical power at the field scale from larger sample sizes. The detected population structure could result from several factors, including different selective pressures from different management practices within the two fields, genetic drift within each population with few migrants between them, or different source populations arriving on transplant seedlings. Potential sources of primary inoculum for gummy stem blight epidemics, including infected seed, transplants, and plant debris, have been identified (Keinath 2002; Koike 1997; Lee et al. 1984). However, it is not entirely clear which of these sources most contributes to primary inoculum that initiates epidemics in greenhouse production of transplants or in the field. Whether epidemics in the field are initiated by infected transplants, infected seed when fields are directly seeded, airborne ascospores from debris, or ascospores or conidia from wild cucurbit species that serve as reservoirs or a combination of factors has yet to be elucidated; however, this study provides insight into the finescale genetic diversity and reproductive biology of $S$. citrulli in the field.

\section{ACKNOWLEDGMENTS}

We thank K. Stevenson (Department of Plant Pathology, University of Georgia) and A. Keinath (Coastal Research and Education Center, Clemson University) for kindly providing isolates and DNA; and S. Bogdanowicz at the Evolutionary Genetics Core Facility at Cornell University for his assistance in identification of microsatellite loci and knowledgeable recommendations for selection and multiplexing of microsatellite markers.

\section{LITERATURE CITED}

Agapow, P. M., and Burt, A. 2001. Indices of multilocus linkage disequilibrium. Mol. Ecol. Notes 1:101-102.

Archie, E. A., Luikart, G., and Ezenwa, V. O. 2009. Infecting epidemiology with genetics: A new frontier in disease ecology. Trends Ecol. Evol. 24:21-30.

Atallah, Z. K., Larget, B., Chen, X., and Johnson, D. A. 2004. High genetic diversity, phenotypic uniformity, and evidence of outcrossing in Sclerotinia sclerotiorum in the Columbia Basin of Washington State. Phytopathology 94:737-742.

Attanayake, R. N., Carter, P. A., Jiang, D., del Río-Mendoza, L., and Chen, W. 2013. Sclerotinia sclerotiorum populations infecting canola from China and the United States are genetically and phenotypically different. Phytopathology 103:750-761.

Avenot, H. F., Thomas, A., Gitaitis, R. D., Langston, D. B., Jr., and Stevenson, K. L. 2012. Molecular characterization of boscalid- and penthiopyradresistant isolates of Didymella bryoniae and assessment of their sensitivity to fluopyram. Pest Manag. Sci. 68:645-651.

Barbara, T., Palma-Silva, C., Paggi, G. M., Bered, F., Fay, M. F., and Lexer, C. 2007. Cross-species transfer of nuclear microsatellite markers: Potential and limitations. Mol. Ecol. 16:3759-3767.

Brewer, M. T., Frenkel, O., and Milgroom, M. G. 2012. Linkage disequilibrium and spatial aggregation of genotypes in sexually reproducing populations of Erysiphe necator. Phytopathology 102:997-1005.

Brewer, M. T., and Milgroom, M. G. 2010. Phylogeography and population structure of the grape powdery mildew fungus, Erysiphe necator, from diverse Vitis species. BMC Evol. Biol. 10:268.

Boerema, G. H., de Gruyter, J., Noordeloos, M. E., and Hamers, M. E. C. 2004. Phoma Identification Manual. Differentiation of Specific and Infraspecific Taxa in Culture. CABI Publishing, Oxfordshire, UK. 
Café-Filho, A. C., Santos, G. R., and Laranjeira, F. F. 2010. Temporal and spatial dynamics of watermelon gummy stem blight epidemics. Eur. J. Plant Pathol. 128:473-482.

Capelle, J., and Neema, C. 2005. Local adaptation and population structure at a micro-geographical scale of a fungal parasite on its host plant. J. Evol. Biol. 18:1445-1454

Chiu, W. F., and Walker, J. C. 1949. Physiology and pathogenicity of the cucurbit black rot fungus. J. Agric. Res. 78:589-615.

Corlett, M. 1981. A taxonomic survey of some species of Didymella and Didymella-like species. Can. J. Bot. 59:2016-2042.

Debuchy, R., and Turgeon, B. G. 2006. Mating-type structure, function, and evolution in Euascomycetes. Pages 293-323 in: The Mycota I. Growth, Differentiation, and Sexuality. U. Kües and R. Fischer, eds. SpringerVerlag, Berlin.

de Neergaard, E. 1989. Studies of Didymella bryoniae (Auersw.) Rehm: Development in the host. J. Phytopathol. 127:107-115.

dos Santos, G. R., da Silva Velloso Ferreira, M. A., de Pinho Pessoa-Filho, A. C., Ferreira, M. E., and Café-Filho, A. C. 2009. Host specificity and genetic diversity of Didymella bryoniae from Cucurbitaceae in Brazil. J. Phytopathol. 157:265-273.

Dutech, C., Enjalbert, J., Fournier, E., Delmotte, F., Barrés, B., Carlier, J., Tharreau, D., and Giraud, T. 2007. Challenges of microsatellite isolation in fungi. Fungal Genet. Biol. 44:933-949.

Faircloth, B. 2008. msatcommander: Detection of microsatellite repeat arrays and automated, locus-specific primer design. Mol. Ecol. Resour. 8:92-94.

Fournier, E., and Giraud, T. 2008. Sympatric genetic differentiation of populations of a generalist pathogenic fungus, Botrytis cinerea, on two different host plants, grapevine and bramble. J. Evol. Biol. 21:122-132.

Frenkel, O., Portillo, I., Brewer, M. T., Péros, J. P., Cadle-Davidson, L., and Milgroom, M. G. 2012. Development of microsatellite markers from the transcriptome of Erysiphe necator for analysing population structure in North America and Europe. Plant Pathol. 61:106-119.

Hauswaldt, J., and Glenn, T. C. 2003. Microsatellite DNA from the Diamondback terrapin (Malaclemys terrapin). Mol. Ecol. Notes 3:174-176.

Hudson, R. R., and Kaplan, N. L. 1985. Statistical properties of the number of recombination events in the history of a sample of DNA sequences. Genetics 111:147-164.

Keinath, A. P. 2002. Survival of Didymella bryoniae in buried watermelon vines in South Carolina. Plant Dis. 86:32-38.

Keinath, A. P. 2011. From native plant in central Europe to cultivated crops worldwide: The emergence of Didymella bryoniae as a cucurbit pathogen. HortScience 4:532-535.

Keinath, A. P. 2012. Differential sensitivity to boscalid in conidia and ascospores of Didymella bryoniae and frequency of boscalid-insensitive isolates in South Carolina. Plant Dis. 96:228-234.

Keinath, A. P. 2014. Differential susceptibility of nine cucurbit species to the foliar and crown canker phases of gummy stem blight. Plant Dis. 98: 247-254.

Keinath, A. P., Farmham, M. W., and Zitter, T. A. 1995. Morphological, pathological and genetic differentiation of Didymella bryoniae and Phoma spp. isolated from cucurbits. Phytopathology 85:364-369.

Koike, S. T. 1997. First report of gummy stem blight caused by Didymella bryoniae, on watermelon transplants in California. Plant Dis. 81:1331.

Kothera, R. T., Keinath, A. P., Dean, R. A., and Farnham, M. W. 2003. AFLP analysis of a worldwide collection of Didymella bryoniae. Mycol. Res. 107: 297-304.

Lee, D. H., Mathur, S. B., and Neergaard, P. 1984. Detection and location of seed-borne inoculum of Didymella bryoniae and its transmission in seedlings of cucumber and pumpkin. Phytopathology 109:301-308.

Maciel, J. L. N., Ceresini, P. C., Castroagudin, V. L., Zala, M., Kema, G. H. J., and McDonald, B. A. 2014. Population structure and pathotype diversity of the wheat blast pathogen Magnaporthe oryzae 25 years after its emergence in Brazil. Phytopathology 104:95-107.

Malausa, T., Gilles, A., Meglécz, E., Blanquart, H., Duthoy, S., Costedoat, C., Dubut, V., Pech, N., Castagnone-Sereno, P., Délye, C., Feau, N., Frey, P., Gauthier, P., Guillemaud, T., Hazard, L., Le Corre, V., Lung-Escarmant, B., Malé, P.-J. G., Ferreira, S., and Martin, J.-F. 2011. High-throughput microsatellite isolation through 454 GS-FLX titanium pyrosequencing of enriched DNA libraries. Mol. Ecol. Resour. 11:638-644.

McDonald, B. A., and Linde, C. 2002. Pathogen population genetics, evolutionary potential, and durable resistance. Annu. Rev. Phytopathol. 40:349-379.
Milgroom, M. G. 1996. Recombination and the multilocus structure of fungal populations. Annu. Rev. Phytopathol. 34:457-477.

Milgroom, M. G., and Peever, T. L. 2003. The synthesis of plant disease epidemiology and population genetics. Plant Dis. 87:608-617.

Milgroom, M. G., Sotirovski, K., Spica, D., Davis, J. E., Brewer, M. T., Milev, M., and Cortesi, P. 2008. Clonal population structure of the chestnut blight fungus in expanding ranges in southeastern Europe. Mol. Ecol. 17: 4446-4458.

Njambere, E. N., Vandemark, G., and Chen, W. 2010. Development and characterization of microsatellite markers of the fungal plant pathogen Sclerotinia trifoliorum. Genome 53:494-500.

Peakall, R., and Smouse, P. E. 2006. GENALEX 6: Genetic analysis in Excel. Population genetic software for teaching and research. Mol. Ecol. Notes 6: 288-295.

Peakall, R., Smouse, P. E., and Huff, D. R. 1995. Evolutionary implications of allozyme and RAPD variation in diploid populations of dioecious buffalograss Buchlö̈ dactyloides. Mol. Ecol. 4:135-148.

Pritchard, J. K., Stephens, M., and Donnelly, P. 2000. Inference of population structure using multilocus genotype data. Genetics 155:945-959.

Prussin, A. J., II, Li, Q., Malla, R., Ross, S. D., and Schmale, D. G., III. 2014. Monitoring the long-distance transport of Fusarium graminearum from field-scale sources of inoculum. Plant Dis. 98:504-511.

Rieux, A., Halkett, F., de Lapeyre de Bellaire, L., Zapater, M. F., Roussett, F., Ravigne, V., and Carlier, J. 2011. Inferences on pathogenic fungus population structures from microsatellite data: New insights from spatial genetics approaches. Mol. Ecol. 20:1661-1674.

Rozen, S., and Skaletsky, H. 2000. Primer3 on the WWW for general users and for biologist programmers. Methods Mol. Biol. 132:365-386.

Santana, Q. C., Coetzee, M. P. A., Steenkamp, E. T., Mlonyeni, O. X., Hammond, G. N. A., Wingfield, M. J., and Wingfield, B. D. 2009. Microsatellite discovery by deep sequencing of enriched genomic libraries. Biotechniques 46:217-223.

Schenck, N. C. 1968. Epidemiology of gummy stem blight (Mycosphaerella citrullina) on watermelon: Ascospore incidence and disease development. Phytopathology 58:1420-1422.

Schoebel, C. N., Brodbeck, S., Buehler, D., Cornejo, C., Gajurel, J., Hartikainen, H., Keller, D., Leys, M., Ř́čanová, S., Segelbacher, G., Werth, S., and Csencsics, D. 2013. Lessons learned from microsatellite development for nonmodel organisms using 454 pyrosequencing. J. Evol. Biol. 26:600-611.

Schuelke, M. 2000. An economic method for the fluorescent labeling of PCR fragments. Nat. Biotechnol. 18:233-234.

Selkoe, K. A., and Toonen, R. J. 2006. Microsatellites for ecologists: A practical guide to using and evaluating microsatellite markers. Ecol. Lett. 9:615-629.

Smith, J. M., Smith, N. H., O’Rourke, M., and Spratt, B. G. 1993. How clonal are bacteria? Proc. Natl. Acad. Sci. USA 90:4384-4388.

Somai, B. M., Keinath, A. P., and Dean, R. A. 2002. Internal transcribed spacer region 1 and 2 and random amplified polymorphic DNA analysis of Didymella bryoniae and related Phoma species isolated from cucurbits. Phytopathology 92:997-1004.

Stevenson, K. L., Langston, D. B., Jr., and Seebold, K. W. 2004. Resistance to azoxystrobin in the gummy stem blight pathogen documented in Georgia. Online publication. Plant Health Prog.

Stewart, J. E., Turner, A. N., and Brewer, M. T. 2015. Variation in host range in the Didymella bryoniae/Stagonosporopsis caricae species complex pathogenic to cucurbits and papaya. Fungal Biol. 119:370-382.

Tamura, K., Peterson, D., Peterson, N., Stecher, G., Nei, M., and Kumar, S. 2011. MEGA5: Molecular evolutionary genetics analysis using maximum likelihood, evolutionary distance, and maximum parsimony methods. Mol. Biol. Evol. 28:2731-2739.

Wiant, J. S. 1945. Mycosphaerella black rot of cucurbits. J. Agric. Res. 71: 193-213.

Xhaard, C., Barrès, B., Andrieux, A., Bousset, L., Halkett, F., and Frey, P. 2012. Disentangling the genetic origins of a plant pathogen during disease spread using an original molecular epidemiology approach. Mol. Ecol. 21: 2383-2398.

Yuen, J. E., and Andersson, B. 2013. What is the evidence for sexual reproduction of Phytophthora infestans in Europe? Plant Pathol. 62:485-491.

Zwankhuizen, M. J., Govers, F., and Zadoks, J. C. 2000. Inoculum sources and genotypic diversity of Phytophthora infestans in Southern Flevoland, The Netherlands. Eur. J. Plant Pathol. 106:667-680. 